\title{
Speech is Silver, but Silence is Golden. Creative Selection and Constructed Oblivion in the Work of Gregory of Tours
}

Par définition, la mémoire est sélective. Paul Ricœur

It is a common misconception that the foremost task of historians is to collect records. On the contrary, the main endeavour is to omit and select from the overwhelming abundance of past material in order to find - invenire - the pertinent detail from specific enquiries and subjects of interest. As early as the classic lectures in rhetoric, such as Cicero's De Inventione or the simultaneous and anonymously authored Ars rhetorica ad Herennium, the methods for the discovery of arguments are described as inventio. ${ }^{1}$ However, often the convincing point about historical works is that not all the discovered facts were conveyed and most of them were left out. It can be said of all historical periods that reliable historiography comes to the fore by working out the contours and developments, by condensing mere episodes and contributing to the creation of meaning as well as conveying insights. Subsequent generations of scholars have focused their analyses of earlier historical documents on this construct; they called for deconstruction to expose the presumed statements of facts and implications. It was important to correct erroneous finds and inventions (inventiones), and to trace a clear picture of the facts. Since the narrative turn, however, 'narrated' history has gained intrinsic significance. The multiplicity of voices replaces exclusive interpretations of the world and history. Therefore, the prevailing trend for the analysis of historiography is to place less emphasis on verifiability and plausibility, while paying greater attention to writing techniques and media-oriented forms of knowledge transfer, where false recollection and phantoms of remembrance are also taken into account. ${ }^{2}$

However, a review of the compiling writing techniques leads to an advance of knowledge when knowledge practices, the transformation of knowledge and cultural change are the centre of attention. The analysis of such writing techniques is particularly rewarding when knowledge transformation is examined during periods of so-

1 Cicero, De Inventione I,9; cf. Rhetorica ad Herennium I,3: Inventio est excogitatio rerum verarum aut veri similium quae causam probabilem reddant./ "Invention is the devising of matter, true or plausible, that would make the case convincing."; Manfred Kienpointner, Inventio, in: Historisches Wörterbuch der Rhetorik 4 (1998), 561-587; N.J. Green-Pedersen, The Tradition of the Topics in the Middle Ages, Munich 1984.

2 Patrick J. Geary, Phantoms of Remembrance. Memory and Oblivion at the End of the First Millennium, Princeton 1994, cf. Helmut Reimitz, History, Frankish Identity and the Framing of Western Ethnicity (550-850), Cambridge 2015. 
cial upheaval. In these historical situations, what emerged was not the intensified loss of knowledge beyond the everyday context, but rather some form of structural amnesia with whole areas of knowledge being cast into oblivion. ${ }^{3}$ Cultural change was noticeable on all social levels and was conditioned by new general ideas, patterns of reception and a transformation of public audiences. ${ }^{4}$

In the field of medieval history, there are various phases of intensified cultural change: the transition from late antiquity to the Early Middle Ages, the revolution of knowledge in the High Middle Ages, the organisational strategies to cope with the explosion of written knowledge in the Late Middle Ages or the change of the reference framework during the Reformation. The present discussion highlights the initial radical change from late antiquity and the early medieval period and the central role of selection methods exemplified by the contemporary witness and protagonist of change, Gregory of Tours, who died in $594 .{ }^{5}$ His works give an ideal illustration of how he creatively dealt with the knowledge banks, which were at his disposal, through the preparation of excerpts as well as compilation and transmission. The genre of the ten histories, which Gregory developed based on decades of work, is a literary innovation. It represented a novelty in terms of the arrangement of the material, perspective and particularly the linguistic style. Gregory certainly also had to bear in mind a changed audience. He borrowed less for clearly historical works than for hagiography, which was more familiar to him. In this case, he made no distinction between worldly and religious history. As for St Augustine, the Book of Genesis represents a historical book for him. Gregory's ten history books are to a certain extent a sermon about historical matter - and this is important in terms of the selection of material and the methods of persuasion.

\footnotetext{
3 Alain Guerreau, L'Avenir d'un passé incertain. Quelle histoire du Moyen Âge au XXie siècle?, Paris 2001, 136.

4 Hartmut Böhme, Einladung zur Transformation, in: Transformation. Ein Konzept zur Erforschung kulturellen Wandels, ed. by Hartmut Böhme, Göttingen 2011, 7-39.

5 Martin Heinzelmann, Gregor von Tours (538-594). Zehn Bücher Geschichte. Historiographie und Gesellschaftskonzept im 6. Jahrhundert, Darmstadt 1994. Adriaan Breukelaar, Historiography and episcopal authority in sixth-century Gaul. The histories of Gregory of Tours interpreted in their historical context, Göttingen 1994, 14-18; Kathleen Mitchell and Ian Wood (eds.), The World of Gregory of Tours, Leiden u.a. 2002. Peter Brown, Gregory of Tours: Introduction, in: The World of Gregory of Tours, ed. by Kathleen Mitchell and Ian Wood, Leiden 2002, 1-28, 1f.; Luce Pietri und Marc Heijmans, Prosopographie Chrétienne du Bas-Empire. La Gaule Chrétienne (314-614), 2 vols., Paris 2013, 915 954; Martin Heinzelmann, Gregory of Tours. The Elements of a Biography, in: A Companion to Gregory of Tours, ed. by Alexander Callander Murray, Leiden 2016 (Brill's Companions to the Christian Tradition 63), 7-34.
} 


\section{Epitomae: Curse and blessing of abridged versions}

The technique of creating epitomes and producing condensed versions of longer works was common practice in late antiquity. Frequently, only these short versions are preserved. Indeed, sometimes they are so regularly handed on that Markus Dubischar proposed the thesis concerning only a 'survival of the most condensed' texts. ${ }^{6}$ The method of condensing was also used in historiography during the early medieval period. Furthermore, there was general awareness that, for the epitomes of histories, condensing was not only beneficial when the prefaces in the epitomes of literary works repeatedly emphasized that this was simpler and more quickly comprehensible for the reader, and thus that the content was rendered more readily accessible. Gregory of Tours was aware of the negative consequences and that the practice of condensing and selective rendition tends to distort the meaning or could potentially even reverse it. He articulates this in his impressive condemnation, which attracted widespread scholarly interest, and can be newly interpreted under the viewpoint of selection practice. ${ }^{7}$ In the conclusion of the tenth book of his histories, he attempted to oblige forthcoming generations to accept a specific reception of his original work. He writes verbatim:

And though I have written these books in a style somewhat rude, I nevertheless conjure you all, God's bishops who are destined to rule the lowly church of Tours after me, by the coming of our Lord Jesus Christ and the judgment day, feared by the guilty, if you will not be condemned with the devil and depart in confusion from the judgment, never cause these books to be destroyed or rewritten, selecting some passages and omitting others, but let them all continue in your time complete and undiminished as they were left by us. ${ }^{8}$

\footnotetext{
6 Markus Dubischar, Survival of the most condensed? Auxiliary Texts, Communications Theory, and Condensation of Knowledge, in: Condensing texts - condensed texts, ed. by Marietta Horster and Christiane Reitz, Stuttgart 2010, 39-67; cf. Markus Mülke, Der Autor und sein Text. Die Verfälschung des Originals im Urteil antiker Autoren, Berlin etal. 2008; Markus Mülke, Die Epitome - das bessere Original?, in: Condensing texts - condensed texts, ed. by Marietta Horster and Christiane Reitz, Stuttgart 2010, 69-90.

7 Erich Auerbach, Mimesis. Dargestellte Wirklichkeit in der abendländischen Literatur, Tübingen 2001 (first edition 1958), 78-80; Helmut Beumann, Gregor von Tours und der sermo rusticus, in: Wissenschaft vom Mittelalter: Ausgewählte Aufsätze, von Helmut Beumann, Köln 1972, 41-70; Walter Goffart, The Narrators of Barbarian History (AD 550-800). Jordanes, Gregory of Tours, Bede and Paul the Deacon, Princeton 1988; Antonio De Prisco, "damnatio" della memoria virgiliana nella "Praefatio" al "Liber in gloria martyrum", in: Proceedings of "Convegno Nazionale di studi su Virgilio” Nocera Inferiore (SA) 2004, 83-95. Mülke, Der Autor und sein Text (note 6), $36 \mathrm{f}$.

8 Gregory of Tours, Libri Historiarum Decem X,31, ed. by Bruno Krusch and Wilhelm Levison, in: MGH SS rer. Merov. 1,1, Hanover ${ }^{2} 1937-1951$, 536: Quos libros licet stilo rusticiori conscripserim, tamen coniuro omnes sacerdotes Domini, qui post me humilem ecclesiam Turonicam sunt recturi, per adventum domini nostri Iesu Christi ac terribilem reis omnibus iudicii diem, sic numquam confusi de ipso iudicio discedentes cum diabolo condempnemini, ut numquam libros hos aboleri faciatis aut rescri-
} 
He strongly condemns the suggestion of the distortion of his text as he left it. ${ }^{9}$ Nobody is permitted to eligere et praemittere (to select and omit) passages from his work. Gregory's condemnation refers to a tradition of condemnations which authors relied on to safeguard their original work. Similar words were already used in the book of Revelation, Chapter 22, Verses 18-19. However, they focus to a lesser extent on the technique of falsification: si quis apposuerit and si quis diminuerit de verbis "if anyone adds to" and "if anyone takes away", then biblical plagues shall be added to him and his share of the tree of life shall be taken away. ${ }^{10}$ Gregory, who obviously knew the text of the apocalypse, and similarly concluded his work with the condemnation, thus took the liberty of giving a more precise account of this biblical condemnation based on his authorial experience.

Other Christian authors had also endeavoured to protect their work. However, it is unknown whether Gregory knew of their warnings and their occasional condemnations. The earliest explicit author is Hieronymus, an important translator and interpreter of Greek and Hebraic knowledge and an intermediary for Western Christianity. In Letter 71.5 he explained how his work was to be treated overall. This letter is significant for the purposes of research not only because of the text-critical and authentication principles developed by Hieronymus, but also for Hieronymus's reflections on copyright. Here, he explicitly criticizes the copyists for not copying what they found, but only what they understood. ${ }^{11}$ The church father Eusebius was

bi, quasi quaedam eligentes et quaedam praetermittentes, sed ita omnia vobiscum integra inlibataque permaneant, sicut a nobis relicta sunt. English translation source: Gregory of Tours, History of the Franks, trans. Ernest Brehaut (extended selections), Records of Civilization 2, New York: Columbia University Press, 1916. http://www.christianiconography.info/gregoryHistoryFranks.htm (last visited 2021-08-01).

9 Relevation 22, 18-19: Contestor enim omni audienti verba prophetiæ libri hujus: si quis apposuerit ad hæc, apponet Deus super illum plagas scriptas in libro isto. Et si quis diminuerit de verbis libri prophetiæ hujus, auferet Deus partem ejus de libro vitae, et de civitate sancta, et de his quæ scripta sunt in libro isto. Rufinus, Historia Ecclesiastica V,20,2, ed. by Eduard Schwartz and Theodor Mommsen, in: Eusebius Werke II,1, Die griechischen christlichen Schriftsteller (GCS) 9,1, Leipzig 1903, 481; Heinzelmann, Zehn Bücher Geschichte (note 5), 84 and 211; Beumann, Gregor von Tours und der sermo rusticus (note 7) 67-70; Mülke, Der Autor und sein Text (note 6), 36; Reimitz, History, Frankish Identity and the Framing of Western Ethnicity (note 2), 20 und 144-159.

10 Apc 22, 18, Biblia vulgata, ed. by Robert Weber and Roger Gryson, Stuttgart 1994, 1905f.: Contestor enim omni audienti verba prophetiæ libri hujus: si quis apposuerit ad hæc, apponet Deus super illum plagas scriptas in libro isto. 19 Et si quis diminuerit de verbis libri prophetiæ hujus, auferet Deus partem ejus de libro vitæ, et de civitate sancta, et de his quæ scripta sunt in libro isto: 20 dicit qui testimonium perhibet istorum. Etiam venio cito: amen. Veni, Domine Jesu. Revelation 22:18-19 English Standard Version (ESV): 18 I warn everyone who hears the words of the prophecy of this book: if anyone adds to them, God will add to him the plagues described in this book, 19 and if anyone takes away from the words of the book of this prophecy, God will take away his share in the tree of life and in the holy city, which are described in this book. Cf. Mühlke, Der Autor und sein Text (note 6), 24.

11 Hieronymus to Lucinus, ep 71,5, ed. by Josef Hilberg, in: Corpus Scriptorum Ecclesiasticorum Latinorum (CSEL) 55, Vienna, Leipzig 1912, 5 f.: ... qui scribunt non, quod inveniunt, sed, quod intellegunt, 
more direct in his demand to the copyists and permitted them to correct the errors, for example, when he writes emendas diligenter, or carefully to amend mistakes. ${ }^{12}$ The translator Rufinus is another important cultural mediator. In the dedication letter to Macharius for the Latin translation of De principis of Origen of Alexandria (ca. 184 to ca. 253) he writes: "However, I oblige everyone ... that he should add nothing to this text, take nothing away, insert nothing, change nothing but compare it with the original ..."13 Rufinus precisely differentiates the types of text falsification: there are two types of additions, namely greater ones, such as could appear at the beginning and end of texts (addere), as well as insertions in the main text (inserere). He refuses to tolerate deletions (aufferre) and changes to the actual wording (immutare). ${ }^{14}$ Cassius Felix might be less well known. In 447, he published a medical compendium based on Greek sources. In a similar way to the apocalypse, he forbade any change by additions or deletions, addendum vel diminuendum. ${ }^{15}$

Compared with the background of possible statements of condemnation, Gregory is unique for his sharpness and precision. This gives the reliable grounds to accept his condemnation of aboleri, rescribere, eligere and praetermittere as a well-known, even familiar technique. As shall be further demonstrated, for the histories he had masterfully perfected the writing technique of the highly-reflected selection of authoritative and well-known facts. Furthermore, he skilfully integrated these into a structure of the divine history of salvation and included well-known stories to narrate his history of salvation. However, in his view he was the only one permitted to leave out and omit content. He therefore refrains from commentary on how he personally inserted the two cited historians, Sulpicius Alexander and Renatus Profuturus Frigiretus, who otherwise were lost to posterity, almost as though they were ornamental spoils in his text (Hist. II, 8 and 9).

et, dum alienos errores emendare nituntur, ostendunt suos; cf. Gert Kloeters, Buch und Schrift bei Hieronymus. Münster 1957, 75; Mülke, Der Autor und sein Text (note 6), 27.

12 Eusebius (transl. by Rufinus), Hist. 5,20 (note 9), 481/483: "adiuro te”, inquit, "qui transcripseris librum hunc, per dominum nostrum lesum Christum, et adventum eius in gloria, cum veniet iudicare vivos et mortuos, ut conferas haec quae scribis et emendes diligenter ad exemplaria, de quibus transcripseris

13 Rufinus, Praef. in libros Origenis Periarchon 1,4, ed. by Paul Koetschau, in: Origenes Werke V. De principiis, GCS 22, Leipzig 1913: illud sane omnem, qui hos libros uel descripturus est uel lecturus, ... contestor atque conuenio per futuri regni fidem, per resurrectionis ex mortuis sacramentum, per illum, qui praeparatus est diabolo et angelis eius, aeternum ignem: sic non illum locum aeterna hereditate possideat, ubi est fletus et stridor dentium et ubi ignis eorum non extinguetur et uermis eorum non morietur, ne addat aliquid huic scripturae, ne auferat, ne inserat, ne inmutet, sed conferat cum exemplaribus, unde scripserit, et emendet ad litteram et distinguat et inemendatum uel non distinctum codicem non habeat, ne sensuum difficultas, si distinctus codex non sit, maiores obscuritates legentibus generet.

14 Mülke, Autor und sein Text (note 6), 30; Klopsch, Anonymität und Selbstnennung mittellateinischer Autoren, in: Mittellateinisches Jahrbuch 4 (1967), 9-25.

15 Cassius Felix, De la médecine, ed. by Anne Fraisse, Paris 2002, LXXIII: ... unde admoneo, fili dulcissime, ne quid forte huic scripturae addendum vel diminuendum existimes. 
Gregory's claim about his discovery of the ultimate interpretation of history in his work was something that he had in common with many later historians. However, he obviously suspected how his work would be treated, hence he issued such a strongly worded statement. It may be considered an irony of history that no other author of the early medieval period was subsequently relied on so frequently as a mine of information for details that were fragmented, rewritten and misused. ${ }^{16}$ This makes it even more valuable to offer a closer insight into his method of selection that was both reflective and creative, as well as offering a highly innovative approach to the past.

\section{Praeteritio: The Open Secret of Paganism}

A brief consideration of Gregory's monologues is worthwhile before describing which criteria he uses to select and arrange his material. The most noteworthy monologues reveal what he explicitly would not choose to convey in his works. In the preface to the Liber in gloria confessorum, a collection of stories of saints, he refers with rhetorical enthusiasm to an extensive list of pagan gods that he intended not to mention. It is relevant to quote Gregory's text at length because of its impressive quality:

Under no circumstance, may we remember the dishonest fables or follow the wisdom of philos-
ophy, that enemy of God, so we do not fall into disgrace at the Last Judgment of eternal death
when God decides. This concern gives me impetus, and it is my wish to describe at length some
of the miraculous reports of the gods that were previously hidden; moreover, I have no intention
of getting caught in these captive nets and becoming ensnared. I am not writing about the es-
cape of Saturn, the fury of Juno, the adultery of Jupiter, not the injustice of Neptune, not
the sceptre of Aeolus and nor about the wars, shipwreck and kingdoms of the Aeneas. I am si-
lent on the dispatch of Cupid, and I do not repeat the love affair and entrapments of Ascanius,
the tears or cruel downfall of Dido, not the horrible forecourt of Pluto, not the lustful abduction
of Proserpina, not the three-headed figure of Cerberus, I do not consider the prophecies of An-
chises, not the falsehoods of Itaka, not Achilles's cunning, not the lies of Sinon. Also, I do not
report Laocoön's advice, not the travails of Hercules and not the conflict, escape and ruinous
end of the Iani. Nor do I write about the different monstrous appearances of the furies, and not
about the other fabulous ideas that this author invented both as lies as well as descriptions in
heroic verses. But all these things are founded on sand and destined to fade quickly, so we turn

16 Heinzelmann, Zehn Bücher (note 5), 89; Monique Goullet and Martin Heinzelmann. La réécriture hagiographique dans l'occident medieval: Transfomations formelles et idéologiques. Beihefte der Francia, vol. 58, Ostfildern 2003, 109-144; Monique Goullet, Écriture et réécriture hagiographiques: Essais sur les réécritures de Vies de saints dans l'Occident latin médiéval (VIII-XIII s.). Hagiologia 4, Turnhout 2005; Helmut Reimitz, The Early Medieval Editions of Gregory of Tours' Histories, in: A Companion to Gregory of Tours, ed. by Alexander Callander Murray, Leiden 2016 (Brill's Companions to the Christian Tradition 63), 519-565. 
now to the divine and evangelical miracles. Here is where the Gospel of St John begins by saying: 'In the beginning was the Word ...'17

It is difficult to surpass the power of negation in this passage with its nineteen repetitions of non. Gregory took the long list of Greco-Roman mythical figures, which are to be rejected, from the first eight books of Vergil's Aeneid that was part of the canon of late antiquity. ${ }^{18}$ This passage has inspired multiple studies, since Gregory expresses his explicit rejection of the pagan world of myths. ${ }^{19}$ He emphasizes this mainly by selecting the negative characters of the Aeneid with malign imaginable attributes.

At first sight, his strategy of defamation seems simple. He lists all the characters from the Aeneid with negative connotations; he implies that they are all despicable even those unnamed figures. However, his approach is more sophisticated. He organizes the names appearing on his negative list not in chronological order, and nor as they appear in Vergil's books. ${ }^{20}$ Rather, he classifies them according to other criteria that are original to him. First, he deals with the themes of the quarrelling gods - Saturn, Juno, Jupiter and Aeolus. Next, he adopts a general clause to reject everything that the Aeneas stand for: bella, naufragio vel regna - wars, shipwreck and kingdoms. Then, he goes on randomly to name demigods, figures and protagonists of the Underworld, including the abduction of Proserpina; he condemns the epic and

17 Gregory of Tours, Gloria Martyrum, prol., ed. by Bruno Krusch, in: MGH SS rer. Merov. 1,2, Hanover 1885, 37 f.: Non enim oportet fallaces commemorare fabulas neque philosophorum inimicam Deo sapientiam sequi, ne in iudicium aeternae mortis, Domino discernente, cadamus. Quod ego metuens et aliqua de sanctorum miraculis, quae actenus latuerunt, pandere desiderans, non me his retibus vel vinci cupio vel involvi. Non ego Saturni fugam, non Iunonis iram, non Iovis stupra, non Neptuni iniuriam, non Eoli sceptra, non Aeneada bella, naufragio vel regna commemoro. Taceo Cupidinis emissionem, non Ascanii dilectionem emeneosque lacrimas vel exitia saeva Didonis, non Plutonis triste vestibulum, non Proserpinae stuprosum raptum, non Cerberi triforme caput, non revolvam Anchisae colloquia, non Itachis ingenia, non Achillis argutias, non Senonis fallacias. Non ego Laguonthe consilia, non Amphitrionidis robora, non Iani conflictus, fugas vel obitum exitiale proferam. Non Eomenidum variorumque monstrorum formas exponam, non reliquarum fabularum commenta, quae hic auctor aut finxit mendacio aut versa depinxit heroico. Sed ista omnia tamquam super harenam locata et cito ruitura conspiciens, ad divina et euangelica potius miracula revertamur. Unde Iohannes euangelista exorsus est, dicens: In principio erat Verbum, et Verbum erat apud Deum, et Deus erat Verbum.

18 Felix Thürlemann, Der historische Diskurs bei Gregor von Tours. Topoi und Wirklichkeit, Bern 1974 (Geist und Werk der Zeiten 39), 96.

19 De Prisco, damnatio (note 7), 91; Jean Meyers, Citations et réminiscences virgiliennes dans les Libri historiarum de Grégoire de Tours, in: Pallas 41, 1994, 67-90, here 75.

20 Saturn, VI 794; Juno, I,27, I,46f.; Jupiter, Iuppiter, gr. Zeus, son of Saturn, brother to Juno, I,254. Aeolus I,65f., Dido, Queen of Carthago IV,166f.; Juno inferna is Proserpina, VI,139; Laookon, priest from Troy II 40 -249; Cupido, Amor, Eros, son of Venus, I,658 and elswhere; Ascanius, son of Aeneas, I,267 and elsewhere; Dido, daughter of Belus, I,340, founds Carthago, commits suicide; Pluto, VII,327; Proserpina, daughter of Juppiter and Ceres, IV,698 and elsewhere; Cerberus, guardian of Hades, VI,417; Anchises, Trojan, father of Aeneas, II,646f.; I,723; Itaka, home of Ulixes, II,104; Achill, hero of Aenesis I,468, V,804, killed Hector; Sinon, Greek who told the Trojans the lie about the wooden horse II,79 329; Amphytrioniades /stepson of Amphitrions = Herkules VIII, 103, 214. 
stylized harmful chatter of humans and their lies and concludes with the furies and the outlook to other inauthentic fables by Vergil. ${ }^{21}$

The minimal form reveals the author's perceptive intent for structure in referencing what seems unworthy to mention. A short summary below highlights his intent for structure throughout his collected works which has been influential for decades of research.

\section{Negative Inventio}

A further step towards the methodical analysis of the phenomenon of forgetting by means of erasure, deletions and omissions, requires the introduction of a new concept to organize sections of omitted knowledge: the concept of negative Inventio. Since the days of classic rhetoric Inventio was defined as the first principle for the discovery of ideas and arguments. Since Aristotle there were other terms, like topics or heuristics, as well as differentiated techniques for the discovery and organization of subject material. However, Cicero's pragmatic approaches or his attributed text Rhetorica ad Herennium were valuably developed especially in late antiquity and the early medieval period..$^{22}$ Cicero introduces Inventio as a target-oriented process of discovery. ${ }^{23}$ From late antiquity, this topic was handed down and employed as part of the basic canon for tracing suitable and relevant knowledge. The process of finding was described as an authentic process, so the perception of this activity changed from a receptive and rational process to a productive and creative one. With slight variations, the instruction to find is manifested, for example, in the rhetoricians Iulius Victor or Fortunatian (4th century) or the encylopaedians of the early medieval period Martianus Capella (5th century), Cassiodor (approx. 490-583), or Isidore of Seville (approx. 560 -636), whom Alcuin (735-804) also later acknowledges. $^{24}$

The term 'negative Inventio' used in association with Inventio is an active and conscious process. In contrast to the 'intention to find' the focus is on 'finding, yet not intending to have found'. Therefore, negative Inventio implies those reflections that were deliberately designed to omit information. A concrete example of this is

21 Edoardo Bona, Non ego saturni fugam... Cicerone, Virgilio nel Prologo al Liber in gloria martyrum di Gregorio di Tours, in: Tanti affetti in tal momento. Studi in onore di Giovanna Garbarino, ed. by Andrea Balbo, Alessandria 2011, 79-94, here $98 \mathrm{f}$.

22 Renato De Filippis, Loquax pagina. La retorica nell'Occidente tardo-antico e alto-medievale, Roma 2013 (Institutiones 2).

23 Cicero, De Inventione I,9: Inventio est excogitatio rerum verarum aut veri similium quae causam probabilem reddant. cf. Rhetorica ad Herennium 1,3: "Invention is the devising of true things or things that seem like the truth, which render the cause as probable." Cicero also adds a catalogus to find further arguments. cf. here the list of circumstances: quis, quid, ubi, quando, cur, quomodo, quibus adminiculis, De Inventione II,55.

24 Kienpointner, Inventio (note 1), 561-587; De Filippis, Loquax pagina (note 22), 61-65. 
the method adopted by Gregory of Tours. He wrote the history of the Franks. However, his intention was not to compile a historia Francorum - even if later audiences considered this to be so, and several transcripts were described in this manner. Instead, his purpose was to find a narrative context in which he would not write a glorious history of the gens francorum. Therefore, he omitted a great deal of what a historia gentis would have required. Individual text types not only prove more suitable than others for the purpose of constructing historical content in accordance with personal interests. The selection of the form and the specific construction also enabled the pursuit of a strategy of leaving out and omission. ${ }^{25}$

Another example is relevant here. Gregory remains silent about his election as bishop at the Paris Synod in 573 as well as his investiture in Tours. ${ }^{26}$ However, a contemporary poem by Venantius Fortunatus has survived about his ceremonial entry to the diocesan city with evidence of closeness to King Gunthramn. ${ }^{27}$ It is highly probable that Gregory owed his position to the monarch's intervention in diocesan affairs - a course of action, which he explicitly refused in all other cases. Gregory could skilfully avoid this blemish, which weighed heavily on his appointment, by constructing the collected ten books of the histories, so that episodes of his life did not appear as crucial, thus not prejudicing the main statement about the victory of the righteous through god's help. Gregory presents himself in numerous further passages as a tolerant and extremely successful bishop who, wherever matters of the ecclesia are concerned, acts in a superior manner when faced with hostility from religious as well as worldly opponents. ${ }^{28}$ Nevertheless, it weighs heavily that his appointment did not conform to his preferred principles of the bishop's investiture, and it is highly probable that the element of royal participation or another irregularity had to be kept silent. ${ }^{29}$ However, Gregory's narrative is structured so that he need not necessarily comment on his own appointment.

However, aside from this clear positive evidence, it is largely Gregory's implicit tendency and pronounced rejection of certain themes that highlight where his structural silence begins. Specific inconsistencies reveal that he did not constantly follow a final plan, and that he repeatedly altered perspectives. This is manifested in changes if his intended portrayal during his work on the histories. The most impor-

25 Martin Heinzelmann, Hagiographischer und historischer Diskurs bei Gregor von Tours?, in: Aevum inter utrumque. Mélanges offerts à Gabriel Sanders, ed. by Marc Van Uytfanghe (Instrumenta Patristica 23), Steenbrugis, The Hague 1991, 237-258. Joachin Pizarro, Narrative and the Literary Imagination in Gregory of Tours' Works, in: A Companion to Gregory of Tours (note 16), 337-374. Joaquín Martínez Pizarro, Mixed Modes in Historical Narrative, in: Narrative and History in the Early Medieval West, ed. by Elizabeth M. Tyler and Ross Balzaretti, Turnhout 2006, 91-104.

26 Odette Pontal, Die Synoden im Merowingerreich, Paderborn et al. 1986, 140 -142; Heinzelmann, Zehn Bücher Geschichte (note 5), 34.

27 Venantius Fortunatus, Carmina V,3, ed. by Friedrich Leo, in MGH Auct. Ant. 4,1, Berlin 1881, 106: huic Sigibercthus ovans favet et Brunichildis honori: iudicio regis nobile culmen adest.

28 Gregory of Tours, Hist. V,49 (note 8).

29 Heinzelmann, Zehn Bücher Geschichte (note 5), 49. 
tant principle regarding the arrangement of the histories' subject matter is his idea of the conflicts of the saints. His aim in the sense of his antithetical presentation method was to highlight the antagonism between good and evil and to portray this as a fight of the faithful and enemies of the church. By such means, he avoided pathos and military tales about heroes. ${ }^{30}$ His efforts to avoid a national history reveals his decision about what he felt was worthwhile forgetting, as Paul Ricoeur has described: "One narrative of a drama means forgetting another." 31

Nevertheless, Gregory explicitly problemizes the ratio of silence. Whenever he confesses, for instance, not to have consciously mentioned something, in general, he follows not merely a linguistic but also an educational and moral purpose. In his view, loose talk and spreading rumours about secrets is reprehensible. In an episode integrated in a central section, he describes how one night a drunkard was locked in a Roman church and, confronted by the physical appearance of two saints, became witness to a prophecy that General Aetius would not fall in battle. However, the identity of the party who spread news of the prophecy and dared to divulge god's secret (arcanumque Dei vulgare... audeat) had vanished from the face of the earth. The next morning, the drunkard had scarcely imparted his knowledge when he lost his sight..$^{32}$ Blindness is a harsh penalty for someone who could not keep to himself trusted secrets - even those that he only heard by chance. However, Gregory emphatically describes the penalty as justified: secrets are not to be revealed, even if one knows them and would dearly like to explain them.

Some of Gregory's omissions are only obvious by comparison with his curriculum vitae and his narrated anecdotes in the histories. For instance, he remains silent about why he appeared before King Gunthramn in Orleans as well as the reason for his attendance at the assembly in Lower Besslingen (Luxembourg). ${ }^{33}$ As noted before, Gregory frequently portrays himself as a benevolent and successful bishop. He accordingly also remains silent about his personal involvement in other royal diocesan appointments, ${ }^{34}$ which generally he does not see as the ideal case. Any intervention by the king in diocesan affairs - especially the appointment of the head - was a matter that, according to his principles, was not advantageous for the church's organization, even if it related to him personally.

30 Walter Goffart, Conspicuously Absent. Heroism in the Histories of Gregory 2009, in: The World of Gregory of Tours, ed. by Kathleen Anne Mitchell and Ian N. Wood, Leiden, Boston, Cologne 2002, 365-393; Reimitz, Early Medieval Editions (note 16); Ian Wood, 'Fredegar's Fables', in: Historiographie im frühen Mittelalter, ed. by Anton Scharer and Georg Scheibelreiter, Vienna 1994, 358-366. 31 Paul Ricoeur, Gedächtnis, Geschichte, Vergessen, Munich 2004, 689.

32 Gregory of Tours, Hist. II,7 (note 8), 49f. Et ecce nunc illum propero viventem exinde reducturus! Verumtamen obtestor, ut qui haec audierit sileat arcanumque Dei vulgare non audeat, ne pereat velociter a terra.

33 Gregory of Tours, Hist. VIII, 21 (note 8); cf. Heinzelmann, Zehn Bücher Geschichte (note 5), 61. 34 Heinzelmann, Zehn Bücher Geschichte (note 5), 49. 
Based on later sources, Gregory's silence on various topics can be more easily understood. For example, the previously mentioned addenda by Fredegar or Paulus Diaconus are relevant here. Gregory therefore conveyed three types of sources in relation to his strategic silence: his original texts, texts by contemporaries and texts of subsequent historiographies. However, aside from this clear positive evidence, it is largely Gregory's personal implicit tendencies and pronounced rejection of certain themes that highlight where his structural silence begins. This kind of forgetting history results from blind spots that are opinion-led or caused by prejudices in Gregory's historiography.

Inevitably, this question leads to an examination of the relationship between what can be positively proved and what is not said or unwritten, or about the quality of omissions and the methodological awareness that a lack of knowledge cannot be rejected from the outset as argumentum ex silentio. Alois Hahn already justifiably emphasized that: "Because anyone who talks need not emphasize that he is talking. As for those who keep quiet about silence, would anyone recognize the silence?”35 Representing the genre of historiography, in Gregory's case it emerged how he used omissions as a structural element of his texts. Although Gregory of Tours often keeps silent, there is method to his behaviour. Gregory demonstrated a considerate and thoughtful approach on his implied silence and the omission of names. This can be regarded as part of his more general theory of omission, whenever defects in specific knowledge hierarchies are to be discussed - especially when highly structured texts are under consideration - and schemes are to be identified and highlighted.

\section{Ratio and Creatio: Gregory's Criteria of Selection}

Gregory of Tours left a legacy of extensive work by the standards of the early medieval period - ten books of historiography and eight books of hagiography. Research studies often criticize Gregory for his loquaciousness, digressions and erroneous information, and particularly complain that his historiography offends the principles of rational text structure. He already provided apologies, almost in the style of topoi, for his hagiographic works, which offer an insight into his selection and arrangement of material and are intended to protect against contemporary criticism. In the preface to the book on the fame of the confessor, he presents his texts in a works catalogue. Here, he anticipates two potential points of criticism. On the one hand, scholars would not want to count him among authors because his style is too rustic; he makes grammatical errors and even confuses ablatives and accusatives.

35 Alois Hahn, Schweigen als Kommunikation und die Paradoxien der Inkommunikabilität, in: Norm und Krise von Kommunikation. Inszenierungen literarischer und sozialer Interaktion im Mittelalter, Berlin 2006, 93-113, here 93. 
On the other hand, he proposes no useful argument (argumentum utile) in his work. However, he counters this with some thoughtful observations. Firstly, he explains his selection for the martyrs' histories alongside their importance as examples for Christian daily practice with an antiquarian justification. He explicitly stated that it was very difficult to bear (valde molestum erat) that they fell victim to forgetting. ${ }^{36}$ Implicitly, this promises a logic of collection that aims for completeness. The poor language quality was not the central problem. For he writes: "I do your work and with my rustic style I will employ your intelligence. For, as I believe, these writings will offer you a good deed, so that what I write in a brief, rough and dark style, you treat at length in a luminous and brilliant manner in pleasing verse and on more measured pages." 37

There follows an explicit invitation to all those who are unsatisfied by his style to record things in their own stylish verses. The 'invention' of the stilus rusticus, or the idiom of a 'would-be' country farmer is the innovative dimension of Gregory's time. This sort of unpretentious view of one's own art of expression is more than just a submissive topos of modesty. It indicates that Gregory consciously prefers not to place his style in the foreground. What is his intention? Attention should be fixed on his deliberately structured arrangement of individual episodes and examples. Elaborate words should not be convincing, nor should simple arguments. Rather, the focus is on the arguments overall in a coherent work (integrum inlibatumque), where everything is intertwined with everything else and contrasts are permitted as well as a single background interpretation - the divine plan of salvation. The individual who is sure that the appropriate arguments and examples have been chosen and effectively compiled is the only one to accept that wordsmiths can later improve on the style and consolidate the work.

Gregory's clear rejection of the stilus rusticus suggests that he by no means valued this as an ideal. He writes about a false prophet who had impersonated Jesus. During a personal encounter, Gregory remarked as follows: "His speech was uneducated (sermo rusticus), the breadth of his language was obscene and ugly. No reasonable talk (sermo rationabilis) came from his mouth." ${ }^{38}$ In this case, the rustic speech - clearly a reference to the pronunciation and words - made it impossible to produce a comprehensible structure of ideas. Therefore, no ratio could be achieved by this means.

36 Gregory of Tours, Liber in gloria confessorum, Praefatio, ed. by Bruno Krusch, in: MGH SS rer. Merov. 1,2, Hanover 1885, 297-298: ...quia valde molestum erat, ut traderentur oblivioni.

37 Ibid: Opus vestrum facio et per meam rusticitatem vestram prudentiam exercebo. Nam, ut opinor, unum beneficium vobis haec scripta praebebunt, scilicet ut, quod nos inculte et breviter stilo nigrante discribimus, vos lucide ac splendide stante versu in paginis prolixioribus dilatetis.

38 Gregory of Tours, Hist. 9,6 (note 8), 419: Erat enim ei et sermo rusticus et ipsius linguae latitudo turpis atque obscoena; sed nec de eo sermo rationabilis procedebat. Claude Carozzi, Grégoire de Tours historien?, in: Faire l'événement au Moyen Âge, ed. by Claude Carozzi and Huguette TavianiCarozzi, Aix-en-Provence 2007, 201-218, here 209. 
This perception of his view of the effect of argument and style in the field of hagiography makes it possible to adopt a new approach to his final plan for his ten histories. Previous studies focused on the composition and skilful organization of material, especially the work by Martin Heinzelman and more recently by Helmut Reimitz. Now, the task is to show how heavily Gregory relied on silence and creative omissions to compile his historical works. He structures historical events in a highly selective manner in relation to his own teleological perspective. ${ }^{39}$ A corpus of the political history of ancient Rome was deliberately omitted. By contrast, details regarding Christ's life or the life of the martyr Martin were newly arranged and integrated in Tours. Byzantium, and even Italy are mentioned only to give some contour to events in Gaul. His priority was always to emphasize the bishops as the impetus of Gaul's history of salvation. They were granted the most space and the most episodes which Gregory skilfully integrated. Precisely for this reason, he had no cause to remain silent about the activity of incapable and dishonourable bishops, since due to his large-scale argument structure, he could prove via other passages the effective intervention of god in the sense of justice. He even juxtaposed personalities from his own family whose life achievements were positive and negative, yet without compiling an honourable family history. ${ }^{40}$

In conclusion, it can be asserted that Gregory applied the literary techniques of antiquity in his works to structure and embellish his material. He sometimes omitted unwanted or unimportant matters that made no contribution to the development of the subject in the sense of his inventio. He rejected pagan content such as the protagonists of the Aeneid; besides, it is not surprising that he simply omitted from his historiography antique Emperors or battles that were insignificant for him. Experts have frequently described him as a compiler for his historical work - the 'ten books of histories'. However, this criticism does not do justice to the structural ingenuity with which, thanks to his composition, Gregory relied on specific methods as a form of knowledge concentration such as juxtaposition or emphasis (gradatio). This is particularly noticeable wherever he interrupted chronologies.

It is precisely through this indirect literary technique, which involves the industrious interweaving of quotations, anecdotes and other text elements, that a convincing individual authorial personality seems to be in oblivion. Nonetheless, to a certain extent this also seems to have been Gregory's intention, since he purported to convey the truth in an unrhetorical and rustic style. Unambiguous examples on the narrative level should confirm the truth through supernatural, divine signs. The numerous, systematically arranged anecdotes should demonstrate that the 'truth' paves its

39 Kathleen Mitchell, Marking the bounds. The distant past in Gregory's History, in: The world of Gregory of Tours, ed. by Kathleen Anne Mitchell and Ian N. Wood, Leiden, Boston, Cologne 2002, 295-306, here 296.

40 Heinzelmann, Zehn Bücher Geschichte (note 5), 7. 
own way and must not be rhetorically transformed. Gregory composes and links themes and motifs, whereas other authors might also take over the linguistic orchestration. 